Journal of

Business and Strategic

Management

(JBSM)

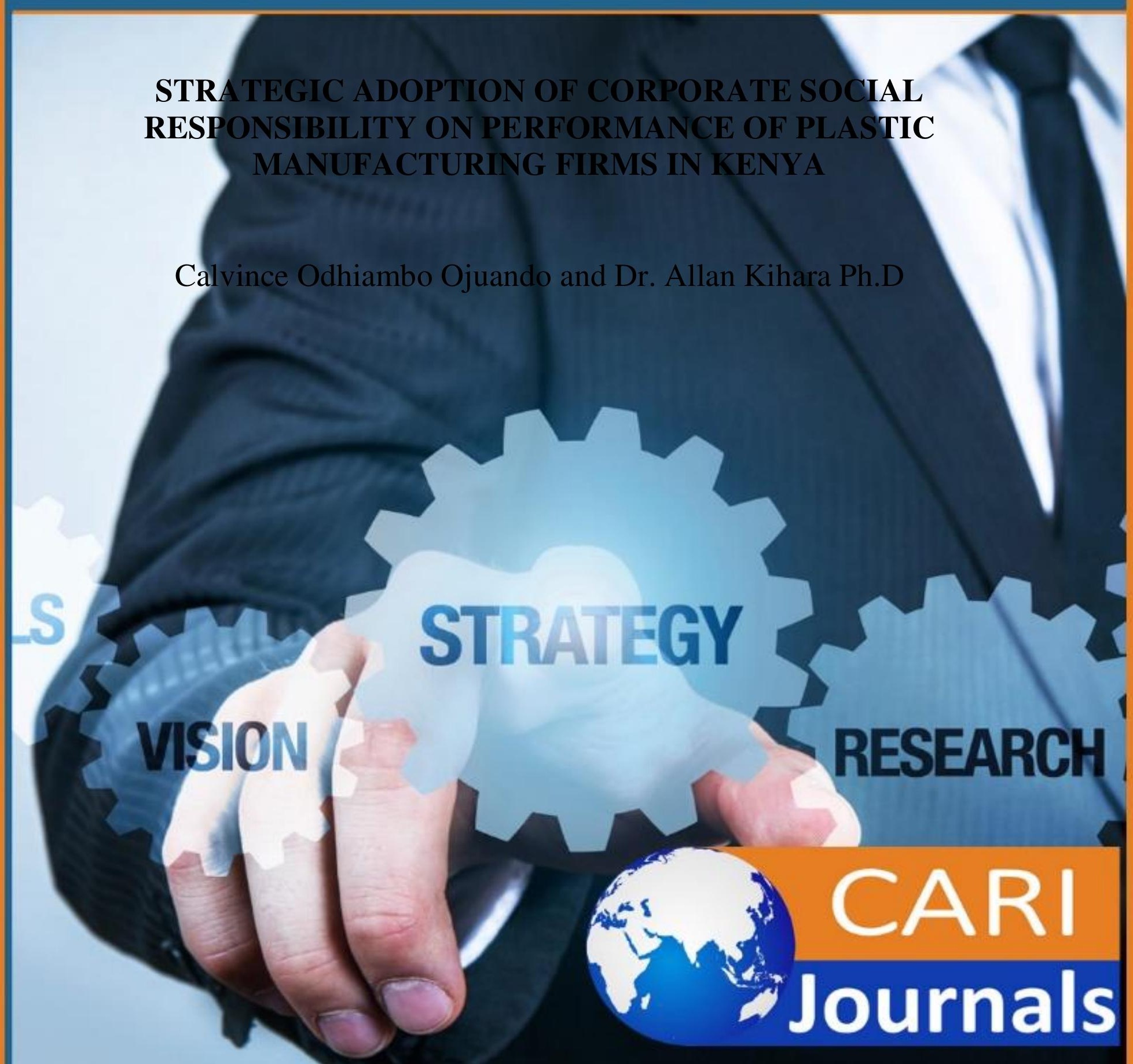




\title{
STRATEGIC ADOPTION OF CORPORATE SOCIAL RESPONSIBILITY ON PERFORMANCE OF PLASTIC MANUFACTURING FIRMS IN KENYA
}

Calvince Odhiambo Ojuando

College of Human Resource and Development, Jomo Kenyatta University of Agriculture and Technology

P. O. Box 62000, 00200 Nairobi, Kenya

Corresponding Author email: calvinceodhiambo@gmail.com

Dr. Allan Kihara Ph.D

College of Human Resource and Development, Jomo Kenyatta University of Agriculture and Technology

P. O. Box 62000, 00200 Nairobi, Kenya

\begin{abstract}
Purpose: The current study sought to establish the strategic adoption of corporate social responsibility on performance of plastic manufacturing firms in Kenya.

Methodology: The study adopted a descriptive survey research design and targeted plastic manufacturing firms registered by Kenya Association of Manufactures. A total of 23 firms were targeted where one manager, two supervisors and two junior staff from the strategic department of the respective firms were involved in the study making a total of 115 respondents. A 5 - point Likert scale questionnaire containing close ended questions was used for collecting data. The data collected was analyzed by employing both inferential analysis and descriptive statistics using MS Excel and SPSS software V22. A pilot study was conducted on three firms to assess the validity and reliability of the data collection instrument.

Results: The results and findings of the analysis were presented in form of tables and figures. The study established that Environmental Conservation Initiatives, Ethical Labor Practices, Business Operators Involvement positively and significantly affects performance of plastic manufacturing firms in Kenya as depicted by Beta values of 2.874, 0.167 and 0.251 respectively. This implies that increase in one unit of each of the variables results to an increase in the performance levels with the respective beta values. Philanthropic initiatives however was found to influence performance but to insignificant levels.
\end{abstract}

Unique contribution to theory, practice and policy: The study recommended that there is a need for plastic manufacturing firm to enhance their environmental conservation initiatives as an CSR activity, to promote ethical labor practices as an CSR activity, to enhance the level of involvement of business operators in CSR activities and to promote philanthropic initiatives as an CSR activity since the practices positively influences the performance levels of the firms.

Key Words: Environmental Conservation Initiatives, Ethical Labor Practices, Business Operators Involvement, Philanthropic Activities and Performance of Plastic Manufacturing Firms 


\subsection{INTRODUCTION}

The statuses and influence of multinational firms is proceedingly growing in the economy internationally, which is increasing demands on accountability and responsibilities for environmental and social effects emanating from individual firm's operations (Ahmed, Mahmoud \& Arkan, 2014). The perception of Corporate Social Responsibility (CSR) has been dynamic in the last few decades in respect to changes in environmental and social demands. In 1950s for instance, the critical focus was on the responsibilities of business to the society and performing good deeds for the benefit of the society. In 2000s, CSR has evolved to be one of the key strategic approaches amongst business operations as the strategy aims at creating a friendly operation environment with the aim of enabling firms standing competitively in the markets (Bahman, Kamran \& Mostafa, 2014). The increasing need of uptake of CSR programs have further been prompted by the demands from stakeholders on the incorporation of the practice in business operations. According to Dolan and Rajak (2018), corporate social responsibility is a managerial concept that entails firms integrating environmental and social concerns in operations of businesses and its interactions with stakeholders. The concept is well understood as the means through which a firm attains a balanced environmental, economic and social aspect while simultaneously fulfilling stakeholders and shareholders' expectations.

In another dimension, Tuan (2012) views CSR as a business self-regulating model that enables a firm to be accountable socially to the public and itself. By applying effective CSR practices, a firm is in a position to determine consciously the kind of impact it has in the society. According to Carroll and Shabana (2011), engaging in CSR practices implies that a firm operates in means that positively enhances society conservation rather than negatively interfering with it. The programs also aim at enhancing public relations, customer and stakeholders satisfaction as well as improving the performances of the firm financially. Ferreira, David and Wogochoti (2014) asserts that implementation of CSR provides a firm with advancement opportunities which eventually translates to enhanced performances. Social community enhancement and improved reputations forms the most anticipated CSR results while a short term decline on profitability levels and conflicts between financial and social goals forms the most possible negative outcomes. Operational environment surrounding manufacturing firms is exposed to deterrents of performances such as dynamisms in customer needs, technological changes, globalization, unfavorable legal frameworks as well as high competition (Kanter, 2011). Adoption of strategies that aim at placing a firm at a competitive edge suffices the challenges. CSR has emerged as one of the strategies that manufacturing firms can implement in their business operations. However, there exist discords from various research works on how the practice contributes to performances of the manufacturing firms. The current study will therefore seek to establish the strategic adoption of corporate social responsibility on performance of manufacturing firms with a focus on plastic manufacturing firms.

\section{Statement of the Problem}

Manufacturing firms plays a key role in economic development of countries by creating employment opportunities and contributing to the gross domestic product. The sector however is faced by challenges that act as deterrents to its economic development contribution in the country. According to KNBS (2018), the sector witnessed a decline in growth from $3.6 \%$ in 2015 
to $2.7 \%$ in 2016 and a further decline to $0.2 \%$ in 2017 . Additionally, the sector's contribution to GDP declined from $9.4 \%$ in 2015 to $9.1 \%$ in 2016 and a further decline to $8.4 \%$ in 2017 . The declining performances in terms of growth and GDP contribution have been accelerated by adoption of various manufacturing processes in different sectors within the manufacturing sector that can be attributed to environmental and social unfriendliness. Plastic manufacturing firms in Kenya form part of the manufacturing firms and constitute $5 \%$ of the sector. The sector's contribution to GPD has however shown declining trend in the last five years. According to Kenya Association of Manufacturers (2018), the sector's contribution to GPD accounted from the manufacturing sector was $3.29 \%$ in 2014 which declined to $3.27 \%$ in 2015 . In 2016, the sector's contribution was $3.02 \%$ which declined to $2.62 \%$ in 2017 and a further decline to $2.83 \%$ in 2018. The declining trend in the levels of GDP contribution by the firms in the plastic manufacturing sector implies that the firms have been witnessing deteriorating performance levels in the past years.

Adoption of strategic corporate social responsibility programs can play a role in enhancing performances of manufacturing firms. According to World Business Council for Sustainable Development (2016), strategic CSR Programs have the possibility of contributing up to $6 \%$ increase in market value, reducing systematic risks by $4 \%$, reducing cost of debt with above $40 \%$, increasing price premium by more than $20 \%$ and increasing staff retention rates by $50 \%$. To enhance performance of plastic manufacturing, there is need to adopt CSR programs as strategy in the operations of the firms. The current study was conducted to assess strategic adoption of CSR on performances of plastic manufacturing firms in Kenya. The study is further prompted by existence of research gap on the relationship between CSR adoption and performances of firms. Basuony, Elseidi and Mohamed (2014) conducted a study to evaluate the impact of CSR on performances of firm from Mena county in Egypt. The study established that CSR programs positively impacts performances of firms. The study was however conducted in Egypt and focused on firms in general. A study by Conesa et al ., (2014) sought to assess the effects of CSR on organizational performances and innovation and focused on SMEs operating in Spain. The study established that CSR forms one of the key performance driver and innovation on organization. The study was however conducted in Spain and focused on SMEs. Another study by Enahoro, Adedayo and Oladele (2013) assessed the relationships between CSR and performances manufacturing firms in Nigeria. The study established that adoption of key CSR programs boosts performances of manufacturing firms in the long run. This study was conducted in the context of manufacturing firms but in Nigeria. The current study sought to fill the existing knowledge gap from the past study by assessing the strategic adoption of corporate social responsibility on performance manufacturing firms in Kenya by focusing on plastic manufacturing firms.

\section{Objectives of the Study}

i. To establish the effects of Environmental Conservation Initiatives on performance of plastic manufacturing firms in Kenya

ii. To find the effects of Ethical Labour Practices on performance of plastic manufacturing firms in Kenya

iii. To examine the effects of Business Operators Involvement on performance of plastic manufacturing firms in Kenya 
Journal of Business and Strategic Management

ISSN 2520-0402 (Online)

Vol.6, Issue No. 4, pp 42-62, 2021

Www.carijournals.org

iv. To determine the effects of Philanthropic activities on performance of plastic manufacturing firms in Kenya

\subsection{LITERATURE REVIEW}

\subsection{Theoretical Review}

The theory was proposed by Deegan(2002) and states that firms progressively pursue objectives with the aim of ensuring that their operations are bound within the norms of the society they are operating in. This is to mean that firms seek to ensure existence of legit approval of their activities by the society (Unerman \& Deegan, 2011). According to the theory, operations of firms are influenced by the society they operate in and at the same time these operations directly or indirectly affect the society. Prevailing economic, political and social environment functions inseparably where a firm needs to consider each of the environment and adjust to ethical changes from their operational environment. Deegan (2002) posits that legitimacy theory acts as a mechanism for supporting firms in their process of developing and implementing voluntary environmental and social disclosures aiming at fulfilling their assigned social contract in the society. This contributes to the firm's abilities of recognizing its performance objectives and its survival levels in the prevailing and dynamic operational environment. The theory informs of the importance of undertaking environmental conservation initiatives by firms to ensure their operations agrees with societal laid down values. Execution of manufacturing activities results to interruptions of the livelihood of the environment in their areas of operations. This sometimes creates conflicts between the firms and the society which may lead to performance failures of the firm. Legitimacy theory advocates for execution of activities that tallies with the values of the society and firm can achieve this by getting involved in activities that suffice their created interruptions. The activities may include recycling their wastes and adopting environmental friendly production mechanisms.

\section{Cognitive Moral Development Theory}

The theory was developed by Lawrence Kohlberg in 1958 and argues that there is a need for firms to engage in ethical behaviors in order to be in a position to articulate values within its operations. According to the theory, ethical practices comprises of principles including fairness, equal employee treatment and concern for others. When instances of unethical practices arise in firm's operations, it raises suspicions amongst employees and outsiders that may end up interfering with the operations of firms. The theory lays an emphasis on the means through which an individual reasons and their comprehensions on the statuses of the activity: whether wrong or right. Additionally, the theory emphasizes on practices associated with ethical leadership by attempting to provide an explanation on interactions between organizational leadership and stakeholders such as employees, consumers, and investors. This is because the theory explains mode of reasoning of people when in ethical dilemmas and their capability of gauging the right thing. The leadership of a firm is viewed as the agent through which an enabling work environment is created. According to the theory, managers and leaders within a firm need to inculcate ethical practices in the firm's operations and cascade the same to all other stakeholders. Additionally, the ethical practices need to put in consideration the needs of employees. The theory informs of the need of adopting ethical labor practices that motivates the performances of employees for realization of firms set performance goals and objectives. When a firm considers employee values, it stands at a better performance position since there is commitment by employees in their execution of their assigned duties and responsibility. 


\section{Stakeholder Theory}

The theory was proposed by Edward Freeman and advanced by other scholars in 2002. The theory postulates that a firm has in possession both impact and explicit contracts with different constituents and it is the firm's responsibility to honor the contracts. The theory further suggests that the main obligation of a firm is not just profit maximization but also increasing the level of satisfaction towards shareholders. Firms according to the theory should focus on balancing the interests of various stakeholders attached to various activities and operations in the firm. According to Harrison and Wicks (2013), operations in a firm are integrated to a variety of stakeholders and the firm bears obligations to each of them. Organizations bear the responsibility of treating the stakeholders fairly with the aim of improving their performances and their levels of competitiveness within the market place. The theory assess both external and internal stakeholders associated with operations of a firm. Internal stakeholders majorly comprise of employers and employees who participate directly on a firm's operations. According to Hansen and Spitzeck (2010), the attitudes from support and employees focusing on corporate actions form a critical managerial interest since they form part of the key contributors of success and influence the firms decision making. The theory informs of the need to involve stakeholders in all CSR activities undertaken by the firm. There is also a need to incorporate the voices of stakeholders in the firms' decisions making process especially the decisions that affect them fully. This according to the theory ensures achievement of set firms' goals both in short and long terms.

\section{Resource Based View Theory}

The theory was proposed by Barney in 1991 and provides concise explanation for reason behind involvement of firms in CSR initiatives. The theory argues that internal environment of a firm contributes to competitive advantage. According to Wernerfelt (1984), resources can be perceived as anything that acts as a representation of a firm's weakness or strength. The process of combining unique resources at the firm's disposal provides avenues for the identification of firm's potentiality in achieving its set performance objectives. Remarkably, firms attains competitive advantage sustainably through effectively and efficiently manipulating and controlling the capabilities and resources that tend to be rare, valuable, non-substitutable and hard to duplicate. Therefore, firms attain their set performance objectives through structuring capabilities internally to tally with external environment conditions. According to Prahalad (1994), external factors do not fully determine the source of success to a firm but rather a combination of both internal characteristics and external factors. For a sustainable engagement in CSR associated activities, a firm needs to evaluate its resource endowment and the possible outcomes of the engagement. The theory informs of the needs of evaluating firms' capabilities in terms of resources prior engaging in CSR associated initiatives such as charity works, donations and fundraising activities. 
Journal of Business and Strategic Management

ISSN 2520-0402 (Online)

Vol.6, Issue No. 4, pp 42-62, 2021

www.carijournals.org

\section{Conceptual Framework}

\section{Environmental Conservation \\ Initiatives}

- Environmental pollution

- Waste Management

- Processes Modification

\section{Ethical Labor Practices}

- Gender sensitivity

- Working conditions

- Level of wages and salaries

\section{Business Operators Involvement}

- Supplier involvement

- Shareholders involvement

- Business regulators involvement

\section{Philanthropic Practices}

- Charity works

- Fundraising Initiatives

- Donations

\section{Independent variables}

\section{Dependent Variable}

\section{Figure 1: Conceptual Framework}

\subsection{Empirical Review}

\section{Environmental Conservation Initiatives}

Roman and Olga (2014) conducted a study to assess the relationship between CSR and financial performance of firms in the airline industry in Eastern and Central Europe. The study specifically sought to establish how environmental conservation initiatives, community performance and employee relations affect the financial performances of the airline firms. The study adopted content analysis research design and targeted 20 airline firms operating in the two regions. Secondary data gathered from financial reports on annual basis was used in the study. a regression model was utilized to assess the level of relationships. The result of the study established that CSR activities in areas of environmental conservation initiatives, community performance and employee relations positively related with financial performances of the airline firms.

Ekatah et al.,(2011) sought to establish existence of a relationship between CSR and firm's profitability with a focus on Royal Dutch Shell Plc. The CSR aspects considered in the study included environmental conservation initiatives and investments in social lives of people. The study adopted a case study approach and relied on secondary data collected from financial reports of the firm for a period of 5 years. The analysis of the data collected revealed that 
adoption of CSR activities positively contributes to performance of the firm in terms of profitability. Additionally, activities such environmental conservation initiatives undertaken by the firm enhances the firm's reputation which further contributes positively to improved performances.

Mwancha and Ouma (2017) conducted a study to assess the effects social responsibility initiatives bears on performances of telecommunication firms with a focus on Safaricom. The study specifically sought to assess how various social initiatives such environmental conservation programs and provision of water and health programs affects the levels of sales, market shares and corporate's brand in Safaricom. The study adopted a descriptive research design and targeted 75 respondents in various employment levels in the firm. Questionnaires were the main data collection tools for the study. Qualitative and quantitative analysis approaches were adopted in the study. The results of the study were presented in form of table and figures. The study established that the CSR initiatives undertaken by the firm positively contributed to increased sales market shares and brand reputations.

\section{Ethical Labor Practices}

Dávila and Troncoso (2018) conducted a study to assess how adoption of ethical labor practices in operations of a firm influences the firms commitments to its mandate to the society. The study was conducted in Chile and targeted firms in agro industry, forestry and tourism. A crosssectional and correlation research design was adopted and a total of 89 individuals were involved in the study. The sample was derived through a random sampling approach on a willing basis. The study adopted Likert scaled questionnaires in gathering data. A correlation analysis was adopted in assessing the relationships between the variables of the study. The study established that the various aspects of labor practices adopted in the study positively related with firms' level of commitment in discharging its mandate to the society.

Turon (2017) sought to establish CSR labor practices in the context of logistic firms in Poland. The sector was targeted due to its perceived importance in economic development and the necessity of implementing SCR policies the sector's operations. The study targeted logistic firms operating in the country where the unit of observation was made up of managers manning the firms. Data was collected through online questionnaires due to physical inaccessibility of the firms. The analysis of the data collected revealed that all the logistics firms involved in the study had adopted labor practices that focused on developing the welfare of employees. Some of the labor practices that were identical to all the firms includes adoption of flexible work schedules, attractive remuneration packages, and paid leaves. These practices were seen to significantly contribute to enhanced performance levels.

Adda, Azigwe and Awuni (2016) conducted a study on business ethics and CSR for the growth and success of business in Maastricht School of Management (MSM) in Ghana. The study adopted a quantitative research approach and targeted 160 students from various faculties in the school. Both primary and secondary data were used in the study and were collected through online surveys. Both descriptive and inferential statistics were applied in the analysis and were generated through SPSS. The results of the analysis revealed that adoption of ethical business behavior by a firm positively contributes to the growth and subsequent success of a firm. Additionally, the study established that presence of an ethical code and impacting the same to employees through training positively enhances work relations that contributes to the growth and performance. 


\section{Business Operators Involvement}

Hamidu, Ibrahim and Daneji (2014) sought to explore the roles played by stakeholders engagement and management on the practice of CSR. The main objective of the study was to explore how stakeholders engagement in terms of communication, involvement in strategizing SCR practices, legitimizing the process and decision making processes can contribute of realization of set organizational goals. The results of the study concluded that stakeholders engagement play a key role on influencing the decisions that an organization makes in respect to participating in CSR practices. Of more importance is the fact that the extent to which a firm engages stakeholders determines the levels of realization of set organizational goals.

Carlsson and Högsten (2011) conducted a study to establish the influence of stakeholders on CSR initiatives of a firm with a focus on textile companies in Swedish. The study adopted a qualitative research approach and utilized both secondary and primary data. Primary data was collected through interviews while secondary data was gathered through reviews on the firms' reports and printed materials. The analysis of the collected data revealed that the firms involved in the study majorly involve customers, suppliers, employees and owners as the only stakeholders in firm's CSR initiatives. Consequently, stakeholders plays a key role in influencing a firm's CSR initiatives and that the firms that fully engaged stakeholders ended up achieving the anticipated results of the initiatives.

Tanggamani, Abu and Othman (2017) conducted an exploratory study to assess how incorporation of stakeholders in a firm's CSR contributes to sustainable growth. The study specifically aimed at demonstrating the importance of incorporating stakeholders when formulating a corporate strategy especially due to the fact that a firm's activities not only contribute to development but also impacts the environment and society in general. The study established that execution of CSR activities entails usage of firm's resources whereby stakeholders bears a great interest. This conception prompts the need of involving stakeholders in strategizing on the firm's CSR activities in order to gain support which culminates to realization of set objectives. Additionally, full involvement of the stakeholders ensures continuity in growth of firms since stakeholders contributes significantly to the firms decisions which acts as drivers to performance.

\section{Philanthropic Activities}

Sokro and Agbola (2016) conducted a study to assess the impacts of philanthropic corporate social initiatives on customer loyalty performance in telecommunication firms in Ghana. The study considered initiatives such as donations and participation in charity works and how these initiatives contributes to customer loyalty performances. The study adopted a mail survey to gather data from subscribers of various Telecom firms. Data was collected from a survey of 588 customers and analyzed qualitatively. The findings of the study revealed that though the philanthropic gestures extended by the telecommunication firms benefited the communities, the level of quality of the services and costs of products form the firms casts doubts on the genuiness of the gestures. This negatively affects the level of performances of the customer loyalties.

Umobong and Agburuga (2018) conducted a study to establish the relationship between corporate social responsibility and financial performance of firms quoted in Nigeria. The study specifically sought to establish how employee management and community development initiatives on performance in areas of ROA and ROI. The study relied on secondary data 
gathered for a period of 10 years between 2005 and 2015. The target population comprised of manufacturing firms operating in healthcare, petroleum marketing, and food sector. Logit regression and content analysis were applied in analyzing the corrected data. The results of the study established that community development initiatives negatively related with ROI and ROA.

Mwanja (2016) conducted a study to establish how CSR influences performances of firms listed in NSE. The study specifically sought to assess how philanthropic, environmental and ethical CSR influences performance of the firms. A census was adopted in the study and data collection form was used in gathering data and analyzed through SPSS and content analysis. The results of the study established both philanthropic, environmental and ethical CSR positively influenced performance of the listed firms in terms of profit. The study recommended that the listed firms ought to strengthen their CSR practices and align them with the firms' strategies in order to enhance their performances.

\subsection{RESEARCH METHODOLOGY}

The study adopted a descriptive survey design and targeted plastic manufacturing firms listed by Kenya Association of Manufacturers. According to KAM (2017), there are 26 registered plastic manufacturing firms in Kenya. A total of 23 firms were involved in the study. One manager, two supervisors and two junior staff from the strategic department of the respective firms were involved in the study. The study used structured questionnaires to collect both qualitative and quantitative data captured through a 5-point likert scale. Inferential and descriptive statistics was used to analyze data. Results of the analysis were presented by use of tables and figures. Inferential statistics was used to establish the association between independent variables and dependent variable. The study used the following regression model:

$Y=\beta_{0}+\beta_{1} X_{1}+\beta_{2} X_{2}+\beta_{3} X_{3}+\beta_{4} X_{4}+\varepsilon$

$\mathrm{Y}=$ Performance of plastic Manufacturing Firms, $\mathrm{X} 1=$ Environmental Conservation Initiatives, $\mathrm{X} 2=$ Ethical Labor Practices, $\mathrm{X} 3=$ Business Operators Involvement, $\mathrm{X} 4=$ Philanthropic Initiatives, $\alpha=$ regression coefficient (constant), $\beta 1, \beta 2, \beta 3$ and $\beta 4=$ coefficients of various independent variable and $\varepsilon=$ error term

\subsection{RESULTS}

The study administered 115 questionnaires to the target respondents comprising of Managers, Supervisors and Officers from 23 plastic manufacturing firms. A total of 98 questionnaires were responded to and returned. This accounted for $85.2 \%$ response rate. The response rate was considered adequate and appropriate for conducting analysis and making inferences. The appropriateness level was anchored on Mugenda and Mugenda (2013) assertions who noted that a response rate of $70 \%$ and above is very good for analysis. The high response late was attributed to giving the respondents sufficient time in responding to the questionnaires and applying a drop and pick data collection technique.

\subsection{Descriptive Statistics}

Descriptive statistics were adopted in the study as the statistics enabled the researcher to describe the distribution of measures on the items contained in the variables. Both means and standard deviation were adopted as the descriptive statistics in the current study. In developing the descriptive statistics, the researcher first rated the responses using a scale of 1-5 and then presenting the average means and standard deviation per each of the statement. In the 
Journal of Business and Strategic Management

ISSN 2520-0402 (Online)

Vol.6, Issue No. 4, pp 42-62, 2021

$\underline{\text { www.carijournals.org }}$

questionnaire, respondents were presented with statements on each variable and were requested to rate the statements in a scale of 1-5 where 5= Strongly Agree, $4=$ Agree, $3=$ Neutral, $2=$ Disagree and $1=$ Strongly Disagree.

\subsubsection{Environmental Conservation Initiatives}

The first objective of the study aimed at assessing how Environmental Conservation Initiatives affects performance of plastic manufacturing firms in Kenya. The respondents were provided with statements in respect to environmental conservation initiatives and were supposed to indicate their levels of agreement. The results presented in table 1 shows that respondents were in agreement with the statements that the firm has taken initiatives of reducing air pollution (mean=4.54, standard deviation=0.375), that the firm has taken initiatives of reducing water pollution (mean=4.67, standard deviation=0.284), that waste products in the firm are disposed appropriately (mean=4.1, standard deviation=0.981) and that the firm recycles its wastes to useful products(mean=3.98, standard deviation=0.913). Respondents further agreed that the firm have adopted environmental friendly production methods (mean=3.88, standard deviation=0.938), that the firm have modified production methods to reduce wastes(mean $=3.91$, standard deviation=0.991) and that the firm involves the community in environmental conservation practices $($ mean $=4.12$, standard deviation=0.934). On average, all respondents were in agreement with statements on environmental conservation initiatives as shown by average response mean of 4.17 and average standard deviation of 0.773 . The results concurs with Roman and Olga (2014) who noted inclusion of environmental conservation practices in the operations of a business have been perceived to be of benefits to firms in areas of environment and financial performances.

\section{Table 1: Descriptive Statistics on Environmental Conservation Initiatives}

\begin{tabular}{lcc}
\hline Statement & Mean & Std Deviation \\
\hline The firm has taken initiatives of reducing air pollution & 4.54 & 0.375 \\
The firm has taken initiatives of reducing water pollution & 4.67 & 0.284 \\
Waste products in the firm are disposed appropriately & 4.1 & 0.981 \\
The firm recycles its wastes to useful products & 3.98 & 0.913 \\
The firm have adopted environmental friendly production methods & 3.88 & 0.938 \\
The firm have modified production methods to reduce wastes & 3.91 & 0.991 \\
The firm involves the community in environmental conservation practices & 4.12 & 0.934 \\
Average & $\mathbf{4 . 1 7}$ & $\mathbf{0 . 7 7 3}$ \\
\hline
\end{tabular}

\subsubsection{Ethical Labor Practices}

The second objective of the study aimed at assessing how ethical labor practices affects performance of plastic manufacturing firms in Kenya. The respondents were provided with statements in respect to ethical labor practices and were supposed to indicate their levels of agreement. The results presented in table 2 shows that respondents agreed to the statements that their respective firm recruits both male and female staffs (mean=4.11, standard deviation=0.991), that managerial positions on the firm are distributed across all genders(mean=3.76, standard deviation=1.098), and that the firm provides the employees with relevant working equipment(mean=3.56, standard deviation=1.134). Respondents further agreed that there is fair compensations in the firm(mean=3.87, standard deviation=0.976), that the firm provides staffs 
with paid leaves(mean=3.98, standard deviation=0.887) and that there are bonuses for good performance $($ mean $=3.89$, standard deviation=0.969). Respondents were however neutral on the statements that there is a flexible work schedule in the firm(mean=3.12, standard deviation=1.342) and that the firm keeps the safety of employees paramount(mean=3.45, standard deviation=1.212). On average, all respondents agreed to the statements of ethical labor practices as shown by average response mean of 3.72 and average standard deviation of 1.076. The results are in tandem with Dávila and Troncoso (2018) findings that incorporation of welfare of employees in various aspects within the work place creates a conducive work environment where each employee discharges their allocated duties and commits themselves towards the realization of the firms' set performance goals and objectives.

Table 2: Descriptive Statistics on Ethical Labor Practices

\begin{tabular}{lcc}
\hline Statement & Mean & $\begin{array}{c}\text { Standard } \\
\text { Deviation }\end{array}$ \\
\hline The firm recruits both male and female staffs & 4.11 & 0.991 \\
Managerial positions on the firm are distributed across all genders & 3.76 & 1.098 \\
There is a flexible work schedule in the firm & 3.12 & 1.342 \\
The firm keeps the safety of employees paramount & 3.45 & 1.212 \\
The firm provides the employees with relevant working equipment & 3.56 & 1.134 \\
There is fair compensations in the firm & 3.87 & 0.976 \\
The firm provides staffs with paid leaves & 3.98 & 0.887 \\
There are bonuses for good performance & 3.89 & 0.969 \\
Average & $\mathbf{3 . 7 2}$ & $\mathbf{1 . 0 7 6}$ \\
\hline
\end{tabular}

\subsubsection{Business Operators Involvement}

The third objective of the study aimed at assessing how business operators' involvement affects performance of plastic manufacturing firms in Kenya. The respondents were provided with statements in respect to business operators involvement and were supposed to indicate their levels of agreement. The results presented in table 3 shows that respondents were in agreement with the statements that the firm involves suppliers in CSR activities (mean=3.84,standard deviation=1.023), that the firm involves shareholders in CSR activities(mean=3.89, standard deviation=1.120) and that the firm involves business regulators in CSR activities (mean=3.91,standard deviation=1.004). Respondents further agreed that the firm values the inputs of the shareholders in its activities(mean=3.71,standard deviation=1.134), that there is engagement of business operators in decision making processes on CSR activities $($ mean=3.88, standard deviation=1.248) and that there is incorporation of business operators opinions in the firms CSR activities(mean=3.56,standard deviation=1.232). On average, all respondents were in agreement with statement on business operators involvement as shown by average response mean of 3.8 and average standard deviation of 1.126. The results concurs with Carlsson and Högsten (2011) who noted that primary objective of involving business operators in a firms' operations is to enhance its relationships with them aiming at bettering their understanding on concerns and perspectives pertaining to critical issues such as CSR and integrating these concerns and perspectives in the formulation of a firm's strategy. 
Journal of Business and Strategic Management

ISSN 2520-0402 (Online)

Vol.6, Issue No. 4, pp 42-62, 2021

www.carijournals.org

Table 3: Descriptive Statistics on Business Operators Involvement

\begin{tabular}{lcc}
\hline Statement & Mean & Std Dev \\
\hline The firm involves suppliers in CSR activities & 3.84 & 1.023 \\
The firm involves shareholders in CSR activities & 3.89 & 1.120 \\
The firm involves business regulators in CSR activities & 3.91 & 1.004 \\
The firm values the inputs of the shareholders in its activities & 3.71 & 1.134 \\
There is engagement of business operators in decision making processes on & 3.88 & 1.248 \\
CSR activities & 3.56 & 1.232 \\
There is incorporation of business operators opinions in the firms CSR & $\mathbf{3 . 8}$ & $\mathbf{1 . 1 2 6}$ \\
activities &
\end{tabular}

\subsubsection{Philanthropic Initiatives}

The fourth objective of the study aimed at assessing how philanthropic initiatives affects performance of plastic manufacturing firms in Kenya. The respondents were provided with statements in respect to philanthropic initiatives and were supposed to indicate their levels of agreement. The results presented in table 4 shows that the firm engages in providing households to the community(mean=4.01, standard deviation=0.671), that the firm organizes periodic charity works to the community (mean=3.97, standard deviation=0.803) and that the firm is involved in medical fund raising activities(mean=3.59, standard deviation=0.998). Remarkably, respondents agreed with the statements that the firm is involved in education fund raising activities (mean $=3.58$, standard deviation=1.023), that there are donations offered by the firm to the less fortunate $($ mean $=4.22$, standard deviation $=0.601)$, that the firm provides donations to charitable organizations(mean=4.12, standard deviation=0.629)and that the firm liaises with other firms in various philanthropic initiatives(mean $=4.16$, standard deviation $=0.731)$. On average, all respondents agreed with the statements on philanthropic initiatives as shown by average response mean of 3.95 and average standard deviation of 0.782 . The findings are in consistent with Umobong and Agburuga (2018) who established that firms engaging in philanthropic activities attains various benefits that contributes to enhanced performances. Activities such as volunteering and charitable contributions increases the level of recognition and reputation of a brand in the highly competitive market.

Table 4: Descriptive Statistics on Philanthropic Initiatives

\begin{tabular}{lcc} 
Statement & Mean & $\begin{array}{c}\text { Standard } \\
\text { Deviation }\end{array}$ \\
\hline The firm engages in providing households to the community & 4.01 & 0.671 \\
The firm organizes periodic charity works to the community & 3.97 & 0.823 \\
The firm is involved in medical fund raising activities & 3.59 & 0.998 \\
The firm is involved in education fund raising activities & 3.58 & 1.023 \\
There are donations offered by the firm to the less fortunate & 4.22 & 0.601 \\
The firm provides donations to charitable organizations & 4.12 & 0.629 \\
The firm liaises with other firms in various philanthropic initiatives & 4.16 & 0.731 \\
Average & $\mathbf{3 . 9 5}$ & $\mathbf{0 . 7 8 2}$ \\
\hline
\end{tabular}


Journal of Business and Strategic Management

ISSN 2520-0402 (Online)

Vol.6, Issue No. 4, pp 42-62, 2021

www.carijournals.org

\subsubsection{Performance of Plastic Manufacturing Firms}

The study sought to establish the performance levels of plastic manufacturing in areas of market share, sales volume and profitability from 2015 to 2019. The first section sought to establish the changes their market share of the firms under study. The results presented in table 5 shows that in $2015,36.1 \%$ of firms had a market share of below $10 \%, 34.2 \%$ had between $10 \%$ and $20 \%$, $10.2 \%$ had between $21 \%$ and $30 \%$ while $36.6 \%$ had above $30 \%$. In $2016,26.1 \%$ of firms had a market share of below $10 \%, 27.1 \%$ had between $10 \%$ and $20 \%, 10.2 \%$ had between $21 \%$ and $30 \%$ while $36.6 \%$ had above $30 \%$. In $2017,57.5 \%$ of firms had a market share of below $10 \%$, $27.6 \%$ had between $10 \%$ and $20 \%, 9.4 \%$ had between $21 \%$ and $30 \%$ while $5.5 \%$ had above $30 \%$. In 2018, 46.3\% of firms had a market share of below 10\%, 26.8\% had between $10 \%$ and $20 \%$, $17.9 \%$ had between $21 \%$ and $30 \%$ while $9 \%$ had above $30 \%$. In $2019,27.1 \%$ of firms had a market share of below 10\%, 18.2\% had between $10 \%$ and $20 \%, 20.1 \%$ had between $21 \%$ and $30 \%$ while $34.6 \%$ had above $30 \%$. The results shows variations in the market share off firm with majority of firms having the lowest market share in 2017 and the highest in 2019

Table 5: Changes in Market Share

\begin{tabular}{lcccc}
\hline Year & Below 10\% & $\mathbf{1 0 \% - 2 0 \%}$ & $\mathbf{2 1 \% - 3 0 \%}$ & Over 30 \% \\
\hline $\mathbf{2 0 1 5}$ & $36.10 \%$ & $34.20 \%$ & $10.20 \%$ & $36.60 \%$ \\
$\mathbf{2 0 1 6}$ & $26.10 \%$ & $27.10 \%$ & $10.20 \%$ & $36.60 \%$ \\
$\mathbf{2 0 1 7}$ & $57.50 \%$ & $27.60 \%$ & $9.40 \%$ & $5.50 \%$ \\
$\mathbf{2 0 1 8}$ & $46.30 \%$ & $26.80 \%$ & $17.90 \%$ & $9 \%$ \\
$\mathbf{2 0 1 9}$ & $27.10 \%$ & $18.20 \%$ & $20.10 \%$ & $34.60 \%$ \\
\hline
\end{tabular}

The second section sought to establish the changes in the firm's sales volume. The results presented in table 6 shows that in 2015, 10.4\% of firms had a sales volume of below Ksh 500m, $21.6 \%$ had sales volume of between ksh $500 \mathrm{~m}$ and ksh $1 \mathrm{~b}, 26.9 \%$ had sales volume of between ksh $1.1 \mathrm{~b}$ and ksh $1.5 \mathrm{~b}, 26.1 \%$ had sales volume of between ksh $1.6 \mathrm{~b}$ and $\mathrm{ksh} 2 \mathrm{~b}$ while $15 \%$ had a sales volume of above ksh 2b. In 2016, $11.9 \%$ of firms had a sales volume of below Ksh 500m, $20.4 \%$ had sales volume of between ksh $500 \mathrm{~m}$ and ksh $1 \mathrm{~b}, 25.5 \%$ had sales volume of between ksh $1.1 \mathrm{~b}$ and ksh 1.5b, 29.9\% had sales volume of between ksh $1.6 \mathrm{~b}$ and ksh $2 \mathrm{~b}$ while $12.3 \%$ had a sales volume of above ksh 2b. In 2017, $45.9 \%$ of firms had a sales volume of below Ksh 500m, $23.4 \%$ had sales volume of between ksh $500 \mathrm{~m}$ and $\mathrm{ksh} 1 \mathrm{~b}, 20.9 \%$ had sales volume of between ksh $1.1 \mathrm{~b}$ and ksh $1.5 \mathrm{~b}$ while $9.8 \%$ had a sales volume of above ksh $2 \mathrm{~b}$. In 2018, 30.2\% of firms had a sales volume of below Ksh 500m, 25.4\% had sales volume of between ksh 500m and ksh $1 \mathrm{~b}, 23.9 \%$ had sales volume of between ksh $1.6 \mathrm{~b}$ and $\mathrm{ksh} 2 \mathrm{~b}$ while $20.5 \%$ had a sales volume of above ksh 2b. In 2019, 10.6\% of firms had a sales volume of below Ksh 500m, 15.9\% had sales volume of between ksh 500m and ksh 1b, 20\% had sales volume of between ksh 1.1b and ksh $1.5 \mathrm{~b}, 23.9 \%$ had sales volume of between ksh $1.6 \mathrm{~b}$ and $\mathrm{ksh} 2 \mathrm{~b}$ while $29.6 \%$ had a sales volume of above ksh $2 \mathrm{~b}$. The results shows that majority of the firms recorded the lowest sales volume between 2017 and 2018 and the highest in 2019.

Table 6: Changes in Sales Volume

\begin{tabular}{lcccccc}
\hline Year & $\begin{array}{l}\text { Below KShs } \\
\mathbf{5 0 0 m}\end{array}$ & $\begin{array}{l}\text { Ksh } \mathbf{5 0 0 m}-\mathbf{k s h} \\
\mathbf{1 b}\end{array}$ & $\begin{array}{l}\text { Ksh } \\
\mathbf{1 . 5 b}\end{array}$ & $\mathbf{1 . 1 b}-\mathbf{k s h}$ & Ksh 1.6b - ksh 2b & Above ksh 2b \\
\hline $\mathbf{2 0 1 5}$ & $10.4 \%$ & $21.6 \%$ & $26.9 \%$ & $26.1 \%$ & $15.0 \%$ \\
$\mathbf{2 0 1 6}$ & $11.9 \%$ & $20.4 \%$ & $25.5 \%$ & $29.9 \%$ & $12.3 \%$ \\
$\mathbf{2 0 1 7}$ & $45.9 \%$ & $23.4 \%$ & $20.9 \%$ & $0.0 \%$ & $9.8 \%$ \\
$\mathbf{2 0 1 8}$ & $30.2 \%$ & $25.4 \%$ & $0.0 \%$ & $23.9 \%$ & $20.5 \%$ \\
$\mathbf{2 0 1 9}$ & $10.6 \%$ & $15.9 \%$ & $20.0 \%$ & $23.9 \%$ & $29.6 \%$ \\
\hline
\end{tabular}


Journal of Business and Strategic Management

ISSN 2520-0402 (Online)

Vol.6, Issue No. 4, pp 42-62, 2021

www.carijournals.org

The third section sought to establish changes in the firm's profitability. The results presented in table 7 shows that in 2015, 27.4\% of firms recorded a profit of below ksh 250m, $25.7 \%$ recorded a profit of between ksh $250 \mathrm{~m}$ and $\mathrm{ksh} 500 \mathrm{~m}, 18.9 \%$ recorded a profit of between $\mathrm{ksh} 501 \mathrm{~m}$ and ksh $750 \mathrm{~m}, 14 \%$ a profit of between ksh $751 \mathrm{~m}$ and ksh $1 \mathrm{~b}$ while $14 \%$ a profit of above ksh $1 \mathrm{~b}$. In $2016,14.9 \%$ of firms recorded a profit of below ksh $250 \mathrm{~m}, 23.3 \%$ recorded a profit of between ksh $250 \mathrm{~m}$ and ksh 500m, 28.4\% recorded a profit of between ksh $501 \mathrm{~m}$ and ksh $750 \mathrm{~m}, 13.8 \%$ a profit of between ksh $751 \mathrm{~m}$ and ksh $1 \mathrm{~b}$ while $19.6 \%$ a profit of above ksh 1b. In 2017, 57.9\% of firms recorded a profit of below ksh $250 \mathrm{~m}, 13.4 \%$ recorded a profit of between ksh $250 \mathrm{~m}$ and $\mathrm{ksh} 500 \mathrm{~m}, 12.9 \%$ recorded a profit of between ksh $501 \mathrm{~m}$ and $\mathrm{ksh} 750 \mathrm{~m}, 11.6 \%$ a profit of between ksh $751 \mathrm{~m}$ and ksh $1 \mathrm{~b}$ while $4.2 \%$ a profit of above ksh $1 \mathrm{~b}$. In $2018,32.2 \%$ of firms recorded a profit of below ksh $250 \mathrm{~m}, 35.4 \%$ recorded a profit of between ksh $250 \mathrm{~m}$ and $\mathrm{ksh}$ $500 \mathrm{~m}, 22.9 \%$ a profit of between ksh $751 \mathrm{~m}$ and $\mathrm{ksh} 1 \mathrm{~b}$ while $9.5 \%$ a profit of above ksh $1 \mathrm{~b}$. In $2019,10.6 \%$ of firms recorded a profit of below ksh $250 \mathrm{~m}, 18.2 \%$ recorded a profit of between ksh $250 \mathrm{~m}$ and ksh 500m, 22\% recorded a profit of between ksh 501m and ksh 750m, 23.9\% a profit of between ksh $751 \mathrm{~m}$ and ksh $1 \mathrm{~b}$ while $25.3 \%$ a profit of above ksh $1 \mathrm{~b}$. The results shows variations in the levels of profits in the years under study with 2017 and 2018 being the years with the least profits and 2015,2016 and 2019 being years with the highest profits.

Table 7: Changes in Profitability Before Tax

\begin{tabular}{lccccc}
\hline Year & $\begin{array}{l}\text { Below KShs } \\
\text { 250million }\end{array}$ & $\begin{array}{l}\text { Ksh 250m - ksh } \\
\text { 500m }\end{array}$ & $\begin{array}{l}\text { Ksh 501m - ksh } \\
\text { 750m }\end{array}$ & $\begin{array}{l}\text { Ksh 751m - ksh } \\
\text { 1b }\end{array}$ & Above ksh 1billion \\
\hline $\mathbf{2 0 1 5}$ & $27.4 \%$ & $25.7 \%$ & $18.9 \%$ & $14.0 \%$ & $14.0 \%$ \\
$\mathbf{2 0 1 6}$ & $14.9 \%$ & $23.3 \%$ & $28.4 \%$ & $13.8 \%$ & $19.6 \%$ \\
$\mathbf{2 0 1 7}$ & $57.9 \%$ & $13.4 \%$ & $12.9 \%$ & $11.6 \%$ & $4.2 \%$ \\
$\mathbf{2 0 1 8}$ & $32.2 \%$ & $35.4 \%$ & $0.0 \%$ & $22.9 \%$ & $9.5 \%$ \\
$\mathbf{2 0 1 9}$ & $10.6 \%$ & $18.2 \%$ & $22.0 \%$ & $23.9 \%$ & $25.3 \%$ \\
\hline
\end{tabular}

\subsection{Inferential Statistics}

\subsubsection{Correlation Results}

The results in table 8 show that environmental conservation initiatives and performance of plastics manufacturing firms positively and significantly correlates. This is shown by a correlation coefficient value of 0.211 and p-value of 0.009 . This bears an implication that enhancing environmental conservation initiatives leads to improved performances amongst plastic manufacturing firms. The results concurs with Roman and Olga (2014) who noted inclusion of environmental conservation practices in the operations of a business have been perceived to be of benefits to firms in areas of environment and financial performances. The results further shows that shows that ethical labor practices and performance of plastics manufacturing firms positively and significantly correlates. This is shown by a correlation coefficient value of 0.321 and p-value of 0.003 . This bears an implication that promoting ethical labor practices leads to improved performances amongst plastic manufacturing firms. The results are in tandem with Dávila and Troncoso (2018) findings that incorporation of welfare of employees in various aspects within the work place creates a conducive work environment where each employee discharges their allocated duties and commits themselves towards the realization of the firms' set performance goals and objectives.

The results also show that business operators involvement and performance of plastics manufacturing firms positively and significantly correlates. This is shown by a correlation 
coefficient value of 0.196 and p-value of 0.012 . This bears an implication that enhancing business operators involvement practices leads to improved performances amongst plastic manufacturing firms. The results concur with Carlsson and Högsten (2011) who noted that primary objective of involving business operators in a firms' operations is to enhance its relationships with them aiming at bettering their understanding on concerns and perspectives pertaining to critical issues such as CSR and integrating these concerns and perspectives in the formulation of a firm's strategy. The results finally shows that philanthropic initiatives and performance of plastics manufacturing firms positively correlates but to insignificant levels. This is shown by a correlation coefficient value of 0.119 and p-value of 0.063 . This bears an implication that enhancing philanthropic initiatives improves performances amongst plastic manufacturing firms to insignificant levels. The findings are in consistent with Umobong and Agburuga (2018) who established that firms engaging in philanthropic activities attains various benefits that contributes to enhanced performances. Activities such as volunteering and charitable contributions increases the level of recognition and reputation of a brand in the highly competitive market.

\section{Table 8: Correlation Analysis}

$\begin{array}{lllll}\text { Environm } & \text { Ethical } & \text { Business } & \text { Philanthropic } & \text { Performance } \\ \text { ental } & \text { Labor } & \text { Operators } & \text { Initiatives } & \text { Of Plastic } \\ \text { Conservati } & \text { Practices } & \text { Involvement } & & \text { Manufacturing } \\ \text { on } & & & & \text { Firms }\end{array}$

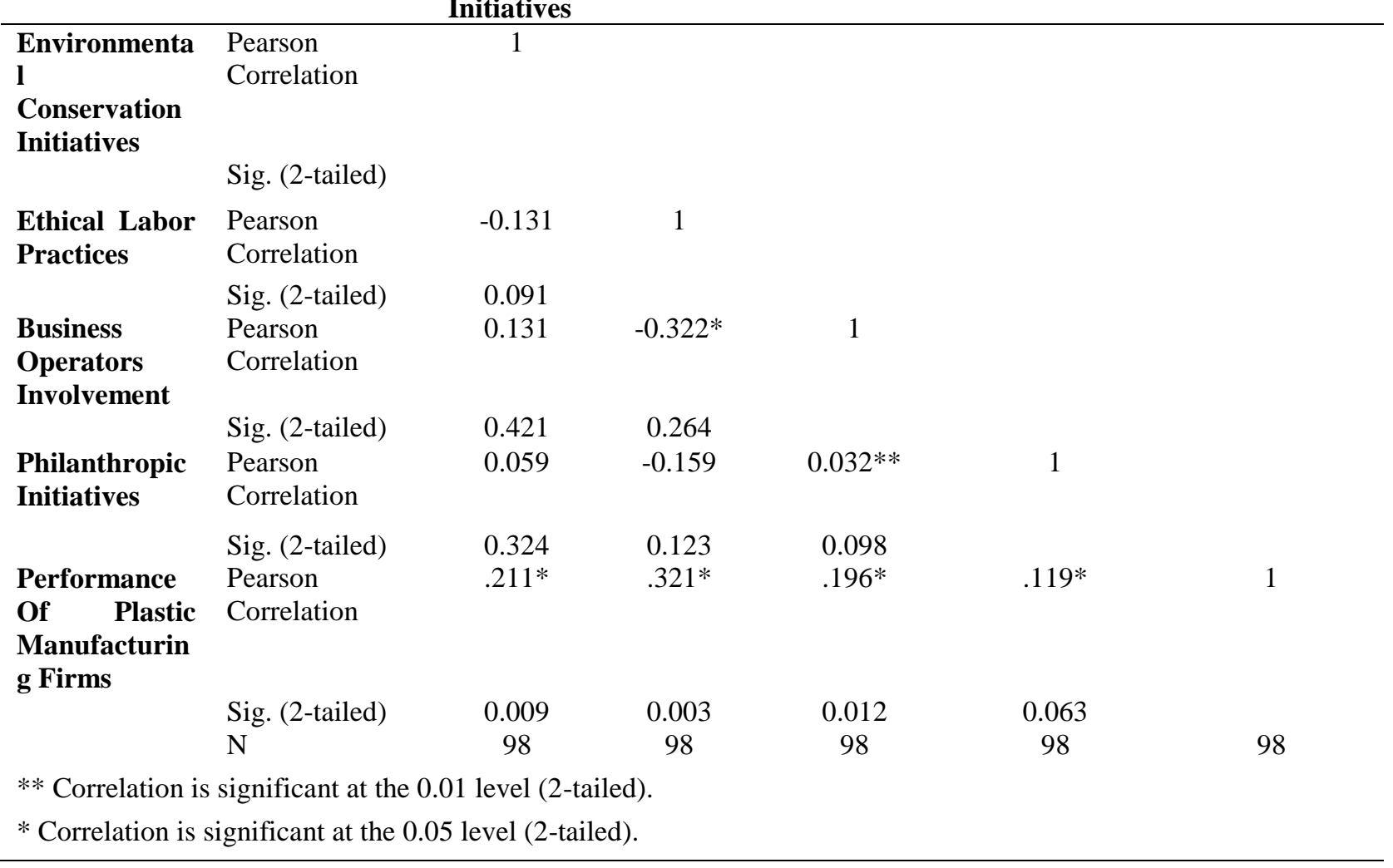


Journal of Business and Strategic Management

ISSN 2520-0402 (Online)

Vol.6, Issue No. 4, pp 42-62, 2021

$\underline{\text { www.carijournals.org }}$

\subsubsection{Multiple Regression Analysis}

A multiple regression analysis aims at assessing the extent to which independent and dependent variables of the study relates. The analysis was conducted at $95 \%$ confidence interval. The results presented in table 9 shows a moderate relationship between environmental conservation initiatives, ethical labor practices, business operators involvement and philanthropic initiatives and performance of plastic manufacturing as shown by $R=0.652$. The coefficient of determination represented by R-Squared value was 0.425 implying that environmental conservation initiatives, ethical labor practices, business operators involvement and philanthropic initiatives accounts for $42.5 \%$ in variations of performance of plastic manufacturing firms.

Table 9: Model Summary

\begin{tabular}{llll}
$\mathbf{R}$ & R Square & Adjusted R Square & Std. Error of the Estimate \\
\hline $.652^{\mathrm{a}}$ & 0.425 & 0.419 & 1.0012321 \\
\hline
\end{tabular}

The study conducted ANOVA test to assess the statistical significance of the model of the study in testing existence of relationships between study variables. According to the results presented in table 10, the model was statistically significant. The level significance was justified by comparing the value of $\mathrm{F}$ calculated which is 13.1358 and $\mathrm{F}$ critical value at $(4,93)$ which is 2.47. The value of $\mathrm{F}$ calculated is more than the value of $\mathrm{F}$ critical hence the model was statistically significant.

Table 10: ANOVA (Model Significance)

\begin{tabular}{llccccc}
\hline & Model & Sum of Squares & df & Mean Square & F & Sig. \\
\hline 1 & Regression & 36.628 & 4 & 9.157 & 13.1358 & $0.01249^{\mathrm{b}}$ \\
& Residual & 64.829 & 93 & 0.6971 & & \\
& Total & 101.457 & 97 & & & \\
\hline
\end{tabular}

Table 11 outlines the model coefficients. The results show existence of a positive and significant effect of environmental conservation initiatives on performance of plastic manufacturing firms. This is shown by a beta value of 0.167 and Sig value of 0.011 . This bears an implication that increasing environmental conservation initiatives with one unit results to 0.167 units increase in the performance of plastic manufacturing firms. The results matches with Roman and Olga (2014) findings that CSR activities in areas of environmental conservation initiatives, community performance and employee relations positively related with financial performances of the airline firms. The results also show existence of a positive and significant effect of ethical labor practices on performance of plastic manufacturing firms. This is shown by a beta value of 0.251 and Sig value of 0.002. This bears an implication that increasing ethical labor practices with one unit results to 0.251 units increase in the performance of plastic manufacturing firms. The results concur with Adda, Azigwe and Awuni (2016) who established that adoption of ethical business behavior by a firm positively contributes to the growth and subsequent success of a firm. 
Journal of Business and Strategic Management

ISSN 2520-0402 (Online)

Vol.6, Issue No. 4, pp 42-62, 2021

www.carijournals.org

The results further shows existence of a positive and significant effect of business operators involvement on performance of plastic manufacturing firms. This is shown by a beta value of 0.116 and Sig value of 0.019. This bears an implication that increasing business operators involvement with one unit results to 0.116 units increase in the performance of plastic manufacturing firms. The results tallies with Tanggamani, Abu and Othman (2017) findings that full involvement of the stakeholders ensures continuity in growth of firms since stakeholders contributes significantly to the firms decisions which acts as drivers to performance. The results finally show existence of a positive but insignificant effect of philanthropic initiatives on performance of plastic manufacturing firms. This is shown by a beta value of 0.091 and Sig value of 0.098 . This bears an implication that increasing philanthropic initiatives with one unit results to 0.091 units increase in the performance of plastic manufacturing firms. The results concurs with Ghosh, Basit and Hassan (2017) findings which established that corporate giving, employee safety and waste reduction bears no significant impact in respect to financial performances of the firms.

Table 11: Model Coefficients

\begin{tabular}{lccccc}
\hline & \multicolumn{2}{c}{$\begin{array}{c}\text { Unstandardized } \\
\text { Coefficients }\end{array}$} & \multicolumn{3}{c}{ Standardized Coefficients } \\
\hline Predictors & B & Std. Error & Beta & T & Sig. \\
\hline (Constant) & 2.874 & 0.175 & & 16.4229 & 0.132 \\
Environmental Conservation Initiatives & 0.167 & 0.111 & 0.157 & 1.5045 & 0.011 \\
Ethical Labor Practices & 0.251 & 0.106 & 0.236 & 2.3679 & 0.002 \\
Business Operators Involvement & 0.116 & 0.101 & 0.109 & 1.1485 & 0.019 \\
Philanthropic Initiatives & 0.091 & 0.109 & 0.084 & 0.8345 & 0.098 \\
\hline
\end{tabular}

The optimal regression model becomes:

Performance of Plastic Manufacturing Firms=2.874+0.251(Ethical Labor Practices) + 0.167(Environmental Conservation Initiatives) $+\mathbf{0 . 1 1 6}$ (Business Operators Involvement) + 0.091(Philanthropic Initiatives)

The model results show that Ethical Labor Practices bears the most significant effect on performance of plastic manufacturing firm, followed by Environmental Conservation Initiatives, then Business Operators Involvement and Philanthropic Initiatives.

\subsection{CONCLUSIONS AND RECOMMENDATIONS}

\section{Conclusions}

The findings of the study led to conclusions that environmental conservation initiatives bear a positive and a significant effect on performance of plastic manufacturing firms in Kenya. Additionally, environmental conservation initiatives such as taking initiatives of reducing air and water pollution, disposing wastes appropriately, recycling wastes into useful products, adopting environmental friendly production methods, modifying production methods to reduce wastes and involving the community in environmental conservation practices positively and significantly affects performance of plastic manufacturing in Kenya. The findings of the study also led to conclusions that ethical labor practices bear a positive and a significant effect on performance of plastic manufacturing firms in Kenya. Additionally, ethical labor practices such as recruiting both male and female staffs, equal distribution of managerial positions across all genders, 
providing employees with relevant working equipment, compensating employees fairly, providing staffs with paid leaves and offering bonuses for good performance positively and significantly affects performance of plastic manufacturing in Kenya.

The findings of the study further led to conclusions that business operator involvement bear a positive and a significant effect on performance of plastic manufacturing firms in Kenya. Additionally, business operator involvement practices such as involving suppliers, shareholders and business regulators in CSR activities, valuing the inputs of the shareholders, engaging of business operators in decision making processes on CSR activities, and incorporating business operators opinions in the firms CSR activities positively and significantly affects performance of plastic manufacturing in Kenya. The findings of the study finally led to conclusions that philanthropic initiative bear a positive but insignificant effect on performance of plastic manufacturing firms in Kenya. Additionally, philanthropic initiative such as engaging in providing households to the community, organizing periodic charity works to the community, participating in medical and education fund raising activities, offering donations to the less fortunate and to charitable organizations and liaising with other firms in various philanthropic initiatives positively but insignificantly affects performance of plastic manufacturing in Kenya.

\section{Recommendations}

The study recommends the plastic manufacturing firms to enhance their environmental conservation initiatives as an CSR activity since the practice positively affects the levels of performance of the firms. The plastic manufacturing firms can achieve this through taking initiatives of reducing air and water pollution, disposing wastes appropriately, recycling wastes into useful products, adopting environmental friendly production methods, modifying production methods to reduce wastes and involving the community in environmental conservation practices. The study also recommends the plastic manufacturing firms to promote ethical labor practices as an CSR activity since the practice positively affects the levels of performance of the firms. The manufacturing firms can achieve this through recruiting both male and female staffs, equally distributing managerial positions across all genders, providing the employees with relevant working equipment, compensating employees fairly, providing staffs with paid leaves and offering bonuses for good performance.

The study further recommends the plastic manufacturing firms to enhance the level of involvement of business operators in CSR activities since the practice positively affects the levels of performance of the firms. The manufacturing firms can achieve this through involving suppliers, shareholders and business regulators in CSR activities, valuing the inputs of the shareholders, engaging of business operators in decision making processes on CSR activities, and incorporating business operators opinions in the firms CSR activities. The study finally recommends the plastic manufacturing firms to promote philanthropic initiatives as an CSR activity since the practice positively affects the levels of performance of the firms. The manufacturing firms can achieve this through engaging in providing households to the community, organizing periodic charity works to the community, participating in medical and education fund raising activities, offering donations to the less fortunate and to charitable organizations and liaising with other firms in various philanthropic initiatives.

\section{ACKNOWLEDGEMENT}

I would like to give thanks to the Almighty for the gift of knowledge and strength that have enabled the completion of this project. I acknowledge the professional support and guidance 
Journal of Business and Strategic Management

ISSN 2520-0402 (Online)

Vol.6, Issue No. 4, pp 42-62, 2021

www.carijournals.org

from my university supervisor Dr. Allan Kihara whose direction and positive critics were fundamental throughout the entire research. I wish to extend my special gratitude to my dear family, friends and the entire JKUAT fraternity for giving me moral support, time and resources to the accomplishment of the project.

\section{REFERENCES}

Adda, G., Azigwe, J., \& Awuni, A. (2016). Business Ethics And Corporate Social Responsibility For Business Success And Growth. European Journal Of Business And Innovation Research, 4(6), 26-42.

Ahmed, W., Mahmoud, K. A. \& Arkan,W.A. (2014). Does corporate social responsibility lead to improve firm financial performance? Evidence of Malaysia. International Journal of Economics and Finance, 6 (3), 126-135.

Bahman, S.P., Kamran, N. \& Mostafa, E. (2014). Corporate Social Responsibility: A Literature review. Academic Journal, 8(7), 228-234

Basuony, M., Elseidi, R., \& Mohamed, E. (2014). The Impact Of Corporate Social Responsibility On Firm Performance: Evidence Form A Mena Country. Corporate Ownership \& Control, 12(1), 761-774.

Carlsson, J., \& Högsten, M. (2011). Stakeholders' Influence on a Company's CSR Initiatives A Case Study of Swedish Textile Companies (Masters). University of Gothenburg.

Carroll, A.B. \& Shabana, K.M. (2011). The business case for corporate social responsibility. UK, Blackwell publishing ltd and British academy of management.

Coca Cola (2016) Community Engagement. Available From: http://www.hindustancocacola.com/community_engagement.asp (Accessed: 05/03/2020).

Conesa, I., Manzano, M., Jorge, M., \& Soto-Acosta, P. (2014). Corporate Social Responsibility And Its Effect On Organizational Innovation And Firm Performance: An Empirical Research In SMES (Postgraduate). University of Murcia, Spain.

Dávila Vera, M., \& Troncoso Andersen, C. (2018). Labor Practices and Organizational Commitment. Ciencia \& Trabajo, 20(63), 145-150.

Deegan, C. (2002), Introduction: The Legitimizing effect of social and environmental disclosures - a theoretical foundation, Accounting. Auditing \& Accountability Journal, 15(3), 282-311

Dolan, C., \& Rajak, D. (2018). The Anthropology of corporate social responsibility. New York: Berghahn.

Ekatah, I., Samy, M., Bampton, R., \&Halabi, A. (2011). The relationship between corporate social responsibility and profitability: The case of Royal Dutch Shell Plc. Corporate Reputation Review, 14(4), 249-261.

Enahoro, J., Adedayo, O., \& Oladele, A. (2013). Corporate social responsibility and financial performance: Evidence from Nigerian manufacturing sector. Asian Journal of Management Research, 4(1), 153-162. 
Journal of Business and Strategic Management

ISSN 2520-0402 (Online)

Vol.6, Issue No. 4, pp 42-62, 2021

www.carijournals.org

Ferreira, C., David, K.D. \& Wogochoti, U. (2014). Reading between the Lines: Financial Reporting, Implied Corporate Social Responsibility and Corporate Financial Performance. New Zealand Finance colloquium. Singapore

Ghosh, B., Basit, A., \& Hassan, Z. (2017). Impact Of Coporate Social Responsibility On Fianncial Performance: A Study On Manufacturing Companies Listed In London Stock Exchange (LSE)-UK. International Journal of Accounting \& Business Management, 5(2), 93-111.

Hidayati, N. (2011). Pattern of corporate social responsibility programs: a case study. Social Responsibility Journal, 7(1), 104-117.

KAM (2017 ) Manufacturing Priority Agenda.Sparking Kenya's Industrial Transformation for job Creation

Kanter, M. R. (2011). Competitive strategy; How great companies think differently. Cambridge Massachusetts, Harvard business publishing.

KNBS (2018). Economics.survey.Available:https://www.knbs.or.ke/download/economic-survey$2018 /$

Mugenda, O., \& Mugenda, A. (2013). Research methods. Nairobi, Kenya: African Centre for Technology Studies.

Mwancha, Y., \& Ouma, C. (2017). Effects of Social Responsibility Initiatives On Performance Of Safaricom Kenya Limited. International Journal of Innovative Research \& Development, 6(8), 252-280.

Mwanja, S. (2016). Influence Of Corporate Social Responsibility On Firm Performance Among Companies Listed On The Nairobi Securities Exchange (Masters). South Eastern Kenya University.

Roman, A., Olga, B. (2014). Corporate Social Responsibility and Financial Performance in the Airline Industry in Central and Eastern Europe

Sokro, E., \& Agbola, R. (2016). The Impact Of Corporate Social Responsibility Performance On Customer Loyalty: Evidence From Ghana. Global Journal Of Business Research, 10(4), 67-82.

Spitzeck, H. and Hansen, E.G. (2010). Stakeholder governance: how stakeholders influence corporate decision making, Corporate Governance, 10 (4). 378-391.

Tanggamani, V., Abu Bakar, S., \& Othman, R. (2017). Incorporating Role of Stakeholders into Corporate CSR Strategy For Sustainable Growth: An Exploratory Study. SHS Web Of Conferences, 36, 00040.

Tilling, M.V. \& Tilt, C.A. (2010). The edge of legitimacy: voluntary social and environmental reporting in Rothman's 1956-1999 annual reports, Accounting and Auditing. Accountability Journal, 23(1),55- 81.

Tuan, L. (2012). Corporate social responsibility, ethics, and corporate governance. Social Responsibility Journal, 8(4), 547-560. 
Journal of Business and Strategic Management

ISSN 2520-0402 (Online)

Vol.6, Issue No. 4, pp 42-62, 2021

www.carijournals.org

Turoń, K. (2017). Corporate Social Responsibility to Employees: The Best Labour Practices in Transport and Logistics Companies. Journal Of Corporate Responsibility And Leadership, 3(1), 37.

Umobong, A., \& Agburuga, U. (2018). Financial Performance and Corporate Social Responsibility of Quoted Firms in Nigeria. International Journal Of Innovative Social Sciences \& Humanities Research, 6(11), 14-30.

World Business Council for Sustainable Development (2016) Corporate Social Responsibility: Meeting Changing Expectations (World Business Council for Sustainable Development, Geneva). 